\title{
Challenges in Controlling Proliferation of Small Arms in Nepal
}

\author{
Subindra Bogati \\ Chief Executive, Nepal Peace Building Initiative \\ Email: subindra@gmail.com
}

\begin{abstract}
The paper aims to study and present the status of proliferation of small arms in Nepal. Nepal has been facing the problems of illicit weapons and this needs proper response from the government so that long-lasting solution can be probed. There is risk of misusing those weapons against anyone. A program to destroy the illegal arms should immediately be launched.
\end{abstract}

Key Words: Small arms, security, conflict, criminal activities

\section{Introduction}

Like many post-conflict societies, Nepal continues to be afflicted by crime and insecurity, fuelled in part by proliferation of small arms (Poudel, 2014). However, it is not clear what kind of firearms are in Nepal or where they are concentrated. Until sometime ago, even minor quarrels resulted in the use of small arms, due to their availability, leading to their abuse even in disputes between family members and acquaintances (Hazen, 2011).

It is often argued that the legacy of the conflict, poor coordination between security agencies of Nepal and India along the open border, low cost of firearms, emergence of armed groups and perennial political instability are the reasons behind the proliferation of the use of small arms (Bogati, 2014). Reports by the Nepal Police and Armed Police Force suggest certain trends in small arms and criminal activities. Small arms are used in a wide range of crimes, including: homicide, attempted homicide, dacoity, kidnapping, theft, robbery, rape and extortion (Nepal Police, 2018).

It is not only criminals or armed groups, but even student leaders affiliated to political parties who seem to be arming themselves with firearms. Poverty, the need for protection, anger, and sentiments of revenge might lead people to feel the need to arm them, or in some cases, they take up small arms for a sense of respect and power. These arms continue to find their way into irresponsible hands.

The porous border between Nepal and India has also fuelled cross-border criminality, particularly the illegal trafficking of small arms and the unchecked movement of criminals between the two countries. The criminal environment is further strengthened by the politicization of crime and criminalization of politics. Criminal and political groups appear to be proliferating, as do the links between the two, and offering protection to each other. However, the use of violence by political parties to intimidate opponents, influence elections and capture public contracts was already 'politics as usual' during the 1990s (Rupantaran, 2012).

The decade long Maoist insurgency in Nepal resulted in more than 17,000 deaths, mainly due to the use of small arms. . A whole cohort of Nepalese adolescents, teens and youth, witnessed extreme violence. This has left a longer - term psychosocial effect on Nepal's younger generation. The multiplication of armed groups and proliferation of small arms in the Terai region caused people to flee their homes while others had to live under the constant threat of weapons.

Nonetheless, the overall security situation has improved in recent years. The reasoning behind the decrease in levels of criminality is threefold: 1) Police have increased their presence throughout Nepal since the end of the conflict; 2) Police are less beholden to and affected by external pressure 
45 | Journal of APF Command and Staff College

from political groups; 3) as a result of negotiations with the government, many armed groups have become inactive or dormant, and have handed over their weapons.

It is also because the conflict concluded with a disarmament and reintegration programme for Maoist combatants. A total of 1,462 combatants were selected for integration into the Nepal Army. Furthermore, in 2007 the Maoists surrendered 3,475 weapons to the United Nations. The small arms arsenal of the UCPN-M has remained the most politically sensitive small arms issue in Nepal. The size and types of weapons in the Maoist People's Liberation Army (PLA)'s total arsenal, including weapons presumed to exist but not surrendered, remains uncertain. Whether the Maoists acquired additional weapons after 2006 is a matter of speculation.

\section{How Many Guns?}

Globally, some 300,000 to half a million people are killed by small arms each year. This means every minute, someone is killed by a gun. The growing availability of small arms has been deemed a major factor in hindering rebuilding and development. Studies worldwide have shown that illicit small arms not only fuel insecurity but also undermine peace initiatives and hamper development activities. They are also a significant factor in fostering a culture of violence.

Maoists insurgency relied on small arms - particularly handguns, 303 rifles captured from the state forces, and a small number of AK-47s; crude weapons such as bladed weapons, stones, sticks, axes: and homemade explosives as tools of warfare. Violent and criminal activities have continued to involve the same means used during the insurgency. These indicate that weapons used in violent incidents and crimes in post-conflict Nepal are not particularly sophisticated.

The magnitude of threats posed by illegal small arms possession in Nepal has not received a through accounting. Neither the Nepal Police nor the Ministry of Home Affairs has exact data on the number of illegal small arms brought into the country or those manufactured in makeshift factories on a daily basis. As government institutions are poorly equipped, they do not have mechanisms for the accurate tracking of legally-owned weapons, let alone illegal ones.

Existing data from the Ministry of Home Affairs suggests that 34,314 people hold licensed firearms in Nepal - mostly in Kathmandu Valley and the Tarai districts (Bogati, 2014). However, Small Arms Survey in 2013 stated that there were around 440,000 private firearms in Nepal, of which 330,000 were unregistered craft weapons (Karp, 2013). Only one-eight of the total firearms, or 55,000, are believed to be legally registered.

As the overall level of weapons possession is low by global standards, it is often argued that Nepal's post-conflict violence involving small arms is less serious and relatively easier to resolve than those of many countries in Africa and Central America. The reason for such a 'low figure' could be due to the lack of funds to procure 'hardware' for the Maoist armed conflict - there are no natural resources in Nepal that could have been exploited and the conflict was not driven by ethnic grievance and so not supported by a 'wealthy' diaspora.

\section{Cost of Illicit Small Arms}

The Kathmandu Valley and other urban hubs as well as a number of Tarai districts are key destinations for illegal arms from black markets in Bihar and Uttar Pradesh in neighbouring India (Racovita, Murray and Sharma, 2013). After the end of conflict, small arms trafficking from the Indian states of Bihar and Uttar Pradesh persisted, with firearms originating in the towns of Banbasa, Gourifanta, Jogbani, Lucknow, Mujjafarpur, Raxaul and Sunouli. There are also concerns about 
Bogati: Challenges in Controlling Proliferation...| 46 small arms moving from China, through Nepal, into India, although little is known of their circulation and use.

The cost is directly affected by their availability and the distance to production sites. It also varies depending on the model and the quality from 2,000 NRs - the cost of an old rudimentary handcrafted pistol - to approximately 60,000 NRs, the cost of a factory or counterfeit weapon. The cost of ammunition varies from 60 to 200 NRs (Nepal Peace building Initiative, 2014).

Brokers operate between India and Nepal, and prices fluctuate depending on how far a weapon has travelled and through the number of middle-men. Ultimately, the cost of illegal small arms and ammunition depends largely on demand factors, and whether conditions necessitate the purchase of an illegal firearm.

Acquiring a firearm legally and obtaining a license can be time consuming and costly. As a result, users may opt to bypass the legal process of procuring a firearm. Furthermore, the cost of factory made weapons - both legal and illegal - is significantly high. Given their cost and difficulty of registration, there appears to be a widespread demand for the cheaper craft handguns or katuwas and improved rifles.

\section{Users of Illicit Small Arms}

Though the main users of the illegal small arms and ammunition are young people, aged 16-30, there are three types of users: criminals; armed groups; and licence-holders whose licenses had expired.

\section{Criminals}

Criminals make up the largest group of users of illicit weapons. Economic reasons and or political rivalries motivate most of the crime-related activities. Criminals use weapons for economically motivated crimes like abduction, victimisation, threat and extortion. They commit these crimes to fulfil their aspirations for the "3 - M" - Money, Machine (Motorcycles, Mobile phones) and Masti (fun). Wildlife crime such as poaching is also a problem in some jungle areas in the Tarai region.

Criminal or criminal gangs are believed to be the largest users of illicit small arms, and are in all kinds of criminal activities, ranging from theft to extortion and contract killings. Before the conflict these groups used traditional weapons like bladed weapons (khukuri), but as firearms became more available in the post-CPA period, they started to use them instead to maintain dominance and control the territory.

\section{Armed Groups}

There is much debate about the number of armed groups active and about their organisations and objectives; in particular whether they are primarily criminal or political in nature (Bogati, Carapic and Muggah, 2013). However, what we know is that armed groups do not have sophisticated weapons at their disposal. Since the end of the conflict, the police have strengthened their presence and armed groups appear to have chosen improvised explosive devices (IEDs), which are often detonated in public areas to create fear and insecurity.

During the peace talks, dozens of armed groups surrendered their arms and ammunition to the District Administrative Office (DAO) or to the Nepal Police. The types of weapons surrendered confirms the fact that they do not have access to modern weapons and operate mainly with traditional knives, guns (katuwas), pistols and bladed weapons. Nevertheless, it is widely believed that many armed groups have not surrendered all of their weapons, and likely hold on to their more sophisticated firearms should they decide to become active once again. 
The least common type of user was license-holders whose licenses had expired. Some license holders formally surrendered their weapons during the MoHA-led nationwide collection programme. MoHA data states that around 35,000 individuals hold licensed firearms in Nepal - mostly in the Kathmandu Valley and districts in the Tarai. However, authorities have failed to maintain records of such firearms. Furthermore, in many of the districts where these records existed, they were lost during the Maoist insurgency.

According to the 1962 Arms and Ammunition Act, a license-holder is required to renew his/her license annually, and failure to do so results in the firearm becoming illegal. The Act also states that carrying illegal small arms and/or ammunition is considered a punishable offence with imprisonment from "three years to five years or with fine from sixty thousands rupees up to one hundred thousand rupees, or both". License-holders can renew their licenses from the DAO across the country.

Since the end of 2012, the Mohan has started recording data of licensed firearms use in a more systematic way. Political parties and civil society organisations argued that small arms, including licensed ones, were used for threats and violence in the 2008 Constituent Assembly. As a result, and with a view toward conducting the elections peacefully, the MoHA issued a public notice requesting the public to temporarily hand over licensed weapons to the DAO before elections in 2013. Following elections, the MoHA continued calling for people with illegal arms to return them voluntarily.

\section{Government Response}

The government has initiated various policies and strategies to curtail the illicit use of firearms in Nepal (although poorly enforced). The Arms and Ammunition Act of 1962 regulates small arms in Nepal. The Act was amended in 2007 delegating more power to the Chief District Officer.

The government of Nepal took a two-pronged strategy in dealing with armed groups. First, in 2009, MoHA implemented a Special Security Plan to curtail the criminal activities of the more than 109 armed groups in the country (Ministry of Home Affairs, 2009). Simultaneously, Ministry of Peace and Reconstruction focused on engaging with politically-motivated groups through a series of peace talks. Despite frequent changes in government coalitions and ministerial representation, the government continued to pursue peace talks with the armed groups.

Further, in 2011, the MoHA started a Small Arms Management Work Plan, with a view to ban the production, transportation, sale, and distribution of small arms in the country. However, the plan has not been made public and its impact is unclear. Similarly, in 2013, the government issued a notice calling for people with illegal arms to return them voluntarily, resulting in the collection of 6,745 firearms. The Nepal Police and the Armed Police Force continue joint operations in the Tarai to limit the transmission of illicit small arms.

The lack of youth employment opportunities is the major driver for their involvement in armed/criminal activities. Studies have shown a proportional relation between unemployed youth and crime. With Nepal Government statistics revealing youth unemployment to be as high as 40 percent, the political instability, weakened institutions and slow economic growth, potentially increases the prospects for youth to be more involved in, and affected by, armed violence. The government has launched relevant plans and policies to encourage the engagement of youth to promote peace and development. For example, the Youth and Small Enterprise Self Employment Fund was launched by 
Bogati: Challenges in Controlling Proliferation...| 48 the Ministry of Finance in 2009. In May 2012, the fund was re-launched and revised with monies channelled through central cooperatives and government - owned banks.

Against a backdrop of political instability, weak institutions and poorly enforced legislation and arms control norms, the Home Ministry and relevant agencies must come up with more creative ways to effectively reduce the danger posed by small arms. Alongside control and reduction measures, underlying causes of the demand for small arms must be investigated. This is because the presence of arms is an indicator, not only of uncontrolled proliferation, but also of perceived need.

Alongside these government-led initiatives are numerous government and non-governmental activities designed to promote peace and reconciliation in areas affected by armed violence. It is expected that the incentive to resort to armed force will diminish if underlying grievances and structural causes of insecurity are addressed. At the forefront of these efforts is the Ministry of Peace and Reconstruction, which has supported the establishment of so-called Local Peace Committees (Ministry of Peace and Reconstruction, 2009).

\section{Conclusion}

The Nepal Police or the government of Nepal should organise a weapons destruction programme to destroy all the illegal weapons collected in the country and currently under the custody of the Nepal Police. At the moment, illicit small arms and ammunition in storage with the Nepal Police are at risk of being looted due to the insecure ways in which they are being stored. Organising a weapons destruction programme would immediately rectify this security risk. Such an initiative would have important symbolic value as a way to demonstrate to the local population and the international community that Nepal has moved beyond conflict, and is now in a period of peace. A weapons destruction programme would also reinforce the local population's trust in security force, and would undermine the morale of criminals and armed groups still operating in the country.

The majority of illicit weapons enter Nepal through the porous southern border with India. The Nepal and Indian Police forces, as well as personnel from the Nepal Army and the Armed Police Force, are currently patrolling the border. Collaboration between Nepalese and Indian authorities and Police is carried out on a case-by-case basis, mainly informally. The Nepal and Indian Police ought to formalise their collaboration along the Tarai border. Enhancing cross-border cooperation between the Nepal and Indian Police would enable both forces to better identify and address the issue of illicit arms flows within and across Indian and Nepalese territory.

Despite positive gains, little remains understood regarding the threat posed by illegal small arms. Neither the Nepal Police nor the MoHA have comprehensive data on illegal arms brought into the country or manufactured in makeshift factories. There is little information available on the different types of firearms currently circulating in Nepal or on the locations and regions they are concentrated. Due to the Nepal Police's limited capacity, it does not have mechanisms to track illegal weapons. The Nepal Police ought to, therefore, enhance, develop, and strengthen its institutional and administrative capacity to deal with illegal small arms and ammunition. One immediate step that can be taken is to organize a Police training programme to enhance the Nepal Police's capacity to document, identify and trace weapons and ammunition.

The precise number of firearms in civilian ownership remains disputed, though figures suggest a severe discrepancy between the number of registered firearms and the number of firearms in use, underlining the need for better registration practices. Tracking illegal arms trafficking without harming the local population remains a delicate matter, as does the collection of illegal firearms currently in civilian possession. 
49 | Journal of APF Command and Staff College

Former license-holders whose licence expired were one of the main categories of illegal small arms and ammunition users. This finding suggests that local citizens might not be aware of Nepal's various laws governing weapons possession and use. This is particularly the case in some of the Terai districts, where the local population speaks languages other than Nepali. Security forces should, therefore, organise a sensitisation programme on firearms legislation and weapons collection. In addition, such a programme should include small arms risk education.

\section{References}

Bogati, S. (2014). 'A Farewell To Arms'. The Kathmandu Post, 11 November. Retrieved from http://kathmandupost.ekantipur.com/news/2014-11-11/a-farewell-to-arms.html

Bogati, S., Jovana, C., and Robert, M. (2013). 'The Missing Middle: Examining the Armed Group Phenomenon in Nepal.' NAVA Issue Brief 1.Geneva: Small Arms Survey.Retrieved from http://www.smallarmssurvey.org/fileadmin/docs/G-Issue-briefs/NAVA-IB1-MissingMiddle.pdf

Bogati, S. (2014). 'Armed and Dangerous'.The Kathmandu Post. Retrieved September 25, 2014, from http://kathmandupost.ekantipur.com/news/2014-09-25/armed-and-dangerous.html

Hazen, J. (2011). 'Armed Violence in the Tarai’, Special Report, Geneva: Small Arms Survey. Retrieved from http://www.smallarmssurvey.org/fileadmin/docs/E-Co-Publications/SASSaferworld-2011-armed-violence-in-the-Terai.pdf

Karp, A. (2013). 'Legacies of war in the company of peace. Firearms in Nepal.'NAVA Issue Brief 2. Geneva: Small Arms Survey. Retrieved from http://www.smallarmssurvey.org/fileadmin/docs/G-Issue-briefs/NAVA-IB2-Legacies-ofWar.pdf

Ministry of Peace and Reconstruction. (2009). Terms of Reference of Local Peace Committees. Kathmandu: Government of Nepal.

Nepal Peacebuilding Initiative.(2014). 'Assessment of Illegal Small Arms and Ammunition Seized by Nepal Police', November, Kathmandu.

Nepal Police. (2018). Original datasets obtained from Nepal Police. February. Kathmandu: Nepal Police.

Paudel, L. ( 2014). 'The Highway Routes: Small Arms Smuggling in Eastern Nepal.' NAVA Issue Brief 4 Geneva; Small Arms Survey.Retrieved from http://www.smallarmssurvey.org/fileadmin/docs/G-Issue-briefs/NAVA-IB4-HighwayRoutes.pdf

Racovita, M., Ryan M., and Sudhindra, S. ( 2013). 'In Search of Lasting Security: An Assessment of Armed Violence in Nepal.' Special Report No. 19. Geneva: Small Arms Survey. Retrieved from http://www.smallarmssurvey.org/fileadmin/docs/C-Special-reports/SAS-SR20-InSearchof-Lasting-Security-NAVA.pdf

Rupantaran, (Nepal). (2012). 'Rupantaran: Promoting Peace in Nepal. Pilot Issue.'October.

Special Security Plan.( 2009). Ministry of Home Affairs. Kathmandu: Government of Nepal. 